\title{
Inhibition of oleandrin on the proliferation and invasion of osteosarcoma cells in vitro by suppressing $W n t / \beta$-catenin signaling pathway
}

Yunlong Ma, Bin Zhu, Xiaoguang Liu,, Huilei Yu, Lei Yong, Xiao Liu, Jia Shao and Zhongjun Liu

\begin{abstract}
Background: Osteosarcoma (OS) is a high-grade bone sarcoma with early metastasis potential, and the clinical chemotherapy drugs that are currently used for its treatment have some limitations. Recently, several studies have reported the selective antitumor effect of oleandrin on various tumor cells. In this study, we aimed to evaluate the effects and underlying mechanisms of oleandrin on OS cells.

Methods: The effect of oleandrin on the proliferation, morphology, and apoptosis of U2OS and SaOS-2 cells were analyzed in vitro. The activity of the Wnt/ $\beta$-catenin signaling pathway was determined using a dual luciferase assay. Semi-quantitative RT-PCR and western blot assays were performed to evaluate the mRNA and total protein expression of the downstream target genes. Changes of $\beta$-catenin in intracellular localization were also explored using a western blot after separating the nucleus and cytoplasm proteins. The MMP-2 and MMP-9 enzymatic activities were determined using gelatin zymography.

Results: Oleandrin significantly inhibited the proliferation and invasion of OS cells in vitro, and induced their apoptosis. After treatment with oleandrin, the TOP/FOP flash ratio in OS cells was noticeably decreased, which indicated that the $W n t / \beta$-catenin signaling pathway was repressed. The expression of related Wnt target genes and total $\beta$-catenin was downregulated, and a reduced nuclear $\beta$-catenin level by oleandrin was observed as well. In addition, oleandrin suppressed the activities of MMP-2 and MMP-9.
\end{abstract}

Conclusions: Oleandrin, in vitro, exerted a strong antitumor effect on human OS cells by suppressing the Wnt/ $\beta$-catenin signaling pathway, which interfered with the proliferation and invasion of OS cells, as well as induced cells apoptosis. Moreover, the expression and activities of MMP-2 and MMP-9 were downregulated by oleandrin, which contributed to the cells' lower invasiveness.

Keywords: Osteosarcoma, Oleandrin, Proliferation, Invasion, Wnt/ß-catenin signaling, Antitumor activity

\section{Background}

Osteosarcoma (OS) is a high-grade malignant bone tumor caused by genetic and epigenetic changes that interrupt osteoblast differentiation from mesenchymal stem cells with a high potential for local destruction and distant metastasis $[1,2]$. OS mainly emerges in regions of active bone growth, such as the knee joint, lower femur and upper tibia, with a high incidence in

\footnotetext{
* Correspondence: xgliudoctor@163.com

Department of Orthopaedics, Peking University Third Hospital, North Garden Street No. 49, Haidian District, Beijing 100191, People's Republic of China
}

adolescents. The treatment for OS, which combines surgery with neoadjuvant and adjuvant chemotherapy, has developed rapidly [3]. Although the use of multi-drug chemotherapy has greatly increased the 5-year survival rate of patients, approximately $30 \%$ of patients experience relapse or metastasis. Importantly, the 5-year survival rate of OS patients with pulmonary metastasis is extremely poor, at $10-20 \%$ [4]. Moreover, a variety of problems also exist with the current therapies, such as chemotherapy tolerance and side effects. This context limits the application of clinical chemotherapy drugs. Therefore, the 
identification a new drug with selective cytotoxicity to tumor cells is urgently needed.

Cardiac glycosides, a type of traditional drug that is used to treat cardiac insufficiency, were recently reported to have an antitumor effect on many tumor cells including breast cancer, lung cancer as well as leukemia [5-7]. Oleandrin is a polyphenolic cardiac glycoside derived from the leaves of Nerium oleander, which has been found to have anti-proliferative effects on tumor cells [5]. The evidence indicates that oleandrin could be a perfect alternative substance due to its selective antitumor and chemoradiation sensitization properties [8]. Moreover, oleandrin recently underwent a Phase I clinical trial as a novel drug for anticancer therapy in patients with refractory solid tumors [9].

There are some reports about the antitumor mechanisms of oleandrin. Cardiac glycosides, such as oleandrin, are known to inhibit the $\mathrm{Na}^{+}, \mathrm{K}^{+}$-ATPase pump, resulting in a consequent increase of calcium influx in the heart muscle [10]. Previous studies reported that oleandrin inhibited the proliferation and induced the apoptosis of cells due to an increase in intracellular $\mathrm{Ca}^{2+}$ via the inhibition of $\mathrm{Na}^{+}, \mathrm{K}^{+}$-ATPase [11]. Oleandrin inhibited the export of fibroblast growth factor-2 through membrane interactions and $\mathrm{Na}^{+}, \mathrm{K}^{+}$-ATPase activity in prostate cancer cells [12]. Oleandrin also induced apoptosis in human leukemia cells through the dephosphorylation of Akt and expression of Fas L, as well as by altering the membrane fluidity [8]. In addition, it suppressed the activation of NF-kB and induced Fas expression and autophagosome formation in tumor cells. The inhibition of Akt phosphorylation and the increase of MAPK expression were also demonstrated in response to oleandrin. The results of these studies have indicated an impending injury and the death of tumor cells following oleandrin treatment. However, no studies have described the antineoplastic activity of oleandrin on osteosarcoma cells and the related mechanisms.

Recent studies have reported the important effect of the $\mathrm{Wnt} / \beta$-catenin signaling pathway in tumorigenesis, bone development and stem cell biology $[13,14]$. Additionally, the role of $\mathrm{Wnt} / \beta$-catenin signaling pathway in the occurrence of osteosarcoma has also been brought to the forefront. The Wnt/ $\mathrm{W}$-catenin pathway is activated when a Wnt ligand binds to its coreceptor complex, which contains a Frizzled family member and low-density lipoprotein receptor-related protein 5/6 (LRP-5/6). Subsequently, disheveled (Dsh) is activated and transmits signals from the receptor to the APC/axin/GSK3 destruction complex to suppress the phosphorylation of $\beta$-catenin by GSK-3 $\beta[15,16]$. Thus, unphosphorylated $\beta$-catenin accumulates in the cytoplasm and translocates into the nucleus, interacts with the T-cell factor/ lymphocyte enhancer factor (TCF/LEF) family of transcription factors and activates downstream target genes, including c-myc, cyclin D1, survivin and matrix metalloproteinase (MMPs), which regulate cell cycle and apoptosis, as well as metastasis [17].

In this study, we aimed to evaluate the effect of oleandrin on OS cell lines in vitro and to investigate the underlying mechanism involved in this process.

\section{Methods}

\section{Cell lines and culture}

$\mathrm{U} 2 \mathrm{OS}$ and SaOS-2 cell lines, derived from the China Infrastructure of Cell Line Resources (Chinese Academy of Medical Sciences, Beijing, China), were cultured in McCoy's 5A (HyClone Laboratories of Thermo Scientific, Logan, UT, USA) and Dulbecco's modified eagle medium (DMEM, HyClone Laboratories of Thermo Scientific, Logan, UT, USA), respectively, which were supplemented with $10 \%$ fetal bovine serum (FBS, HyClone Laboratories of Thermo Scientific, Logan, UT, USA), 100 units $/ \mathrm{ml}$ penicillin and $100 \mu \mathrm{g} / \mathrm{ml}$ streptomycin (Gibco, Life Technologies, Inc., Grand Island, $\mathrm{NY}$ ) in a humidified incubator containing $5 \% \mathrm{CO}_{2}$ at $37{ }^{\circ} \mathrm{C}$. Oleandrin was purchased from Sigma-Aldrich Chemical Co. (St. Louis, CA, USA), and the purity was approximately $99 \%$, as analyzed by HPLC. It was dissolved in $100 \%$ dimethyl sulfoxide (DMSO, SigmaAldrich Chemical Co., St. Louis, CA, USA) and diluted with medium. As a vehicle control, cultured cells were incubated in medium containing DMSO at a final concentration of less than $0.1 \%$.

\section{Cell counting kit-8 (CCK-8) proliferation assay}

U2OS or SaOS-2 cells were seeded in a 96-well dish at a final density of $5 \times 10^{3}$ (U2OS) or $1 \times 10^{4}$ (SaOS-2) cells/ well and were incubated for $24 \mathrm{~h}$. The cells were then treated with oleandrin at increasing concentrations (25, 50, 75, and $100 \mathrm{nM}$ ) and the control medium for 24,48 and $72 \mathrm{~h}$. Thereafter, $10 \mu \mathrm{l} \mathrm{CCK-8} \mathrm{(Dojindo} \mathrm{Laborator-}$ ies, Kumamoto, Japan) was added to each well and incubated for another $3 \mathrm{~h}$. The absorption at $450 \mathrm{~nm}$ was determined for each sample using an automatic ELISA plate reader. Five replicate wells were used for each treatment, and the experiments were repeated three times. Cell viability $(\%)=[\mathrm{OD}$ (treatment)-OD (blank)]/ [OD (control)-OD (blank)] $\times 100 \%$.

\section{Colony formation assay}

U2OS and SaOS-2 cells were seeded into 12-well plates at a density of 100 cells/well. After adherence at $37^{\circ} \mathrm{C}$ in a $5 \% \mathrm{CO}_{2}$ humidified oven for $24 \mathrm{~h}$, the cells were treated with $25 \mathrm{nM}$ and $50 \mathrm{nM}$ oleandrin and the control medium at $37{ }^{\circ} \mathrm{C}$ for 10 days, during which the medium containing the corresponding concentrations of oleandrin was refreshed every 2 days. Ten days later, the 
colonies were fixed with $4 \%$ paraformaldehyde and stained with $0.5 \%$ crystal violet. The number of colonies in each well was counted under an inverted microscope (Leica, Frankfurt, Germany).

\section{DAPI staining}

U2OS and SaOS-2 cells were seeded in 24-well plates and treated with the control or 25 and $50 \mathrm{nM}$ oleandrin for $24 \mathrm{~h}$. The cells were rinsed three times with PBS, and Triton X-100 was added to break the cell membrane integrity for $15 \mathrm{~min}$. Then, DAPI (Beyotime, Shanghai, China) was added for another $10 \mathrm{~min}$ of incubation in the dark. The cell nuclei were observed and photographed at 400x magnification under a fluorescence microscope (Leica DM3000, Frankfurt, Germany).

\section{Apoptosis analysis by flow cytometry (FCM)}

U2OS and SaOS-2 cells were seeded into 6-well plates and adhered overnight. When a confluence of 70-80\% was reached, both cell lines were exposed to $50 \mathrm{nM}$ of oleandrin for 0,24 and $48 \mathrm{~h}$. Subsequently, the cells were collected and re-suspended in $500 \mu \mathrm{l}$ of $1 \times$ binding buffer. Five microliters of annexin V-FITC and $5 \mu \mathrm{l}$ of propidium iodide (PI) were added to all of the samples, which were then incubated at room temperature for $5 \mathrm{~min}$ in the dark according to the manufacturer's protocol from the Annexin V-FITC apoptosis detection kit (BioVision Co, California, USA). The fluorescence intensity of the cells was immediately analyzed by flow cytometry.

\section{Wound-healing assay}

U2OS and SaOS-2 cells were seeded in a 6-well plate and incubated for $24 \mathrm{~h}$. A pipette tip was used to scratch three perpendicular wounds into a cross shape, and the wells were washed twice with PBS to remove the detached cells. U2OS and SaOS-2 cells were treated with $25 \mathrm{nM}$ oleandrin for a corresponding amount of time. Oleandrin were diluted with medium containing $2 \%$ FBS to eliminate the influence of cell proliferation. The wounds were photographed at each time point using an inverted microscope (Leica). The distance migrated was calculated by dividing the distance at the time point by the distance at the beginning. For each experiment, a total of 5 wounds were measured per group, and the results were analyzed using Image J Software.

\section{Transwell invasion assay}

U2OS and SaOS-2 cells were starved in serum-free medium for $24 \mathrm{~h}$ and then re-suspended in serum-free medium with $25 \mathrm{nM}$ oleandrin and the control medium. Then, $5 \times 10^{4}$ cells per well were added to the upper chamber pre-coated with Matrigel (diluted 4-fold with PBS, BD Biosciences, Franklin Lakes, NJ), while the lower chamber was filled with $500 \mu$ l of complete culture medium containing $10 \%$ FBS as a chemo-attractant source. After $24 \mathrm{~h}$ of incubation at $37{ }^{\circ} \mathrm{C}$, the cells that had invaded the lower surface of the membrane were fixed with $75 \%$ ethanol and stained with crystal violet. Using light microscopy, 5 random fields were selected, and the cells in each field were counted under high magnification $(200 \times)$.

\section{Gelatin zymography assay}

U2OS cells were seeded in 6-well plates and incubated with $1 \mathrm{ml}$ of McCoy's 5A medium containing oleandrin for $24 \mathrm{~h}$ after adherence. Then, the supernatant was collected and the protein concentration was determined using the BCA Protein Assay Kit (Applygen Technologies Inc., Beijing, China) according to the manufacturer's protocol. All samples were diluted in $2 \times$ SDS-PAGE nonreducing buffer (4\% SDS, $100 \mathrm{mM}$ Tris- $\mathrm{HCl}$ pH6.8, $20 \%$ glycerol and $0.02 \%$ bromophenol blue), and the mixtures were separated on a SDS-PAGE gel (10\% separation gel containing gelatin). The following processes were performed according to the protocol from the MMP Zymography Assay Kit (Applygen Technologies Inc., Beijing, China). The gel was scanned by a gel documentation system (Bio-Rad Co., Nanjing, China).

\section{Semi-quantitative reverse transcription polymerase chain reaction (RT-PCR)}

For PCR analysis, U2OS cells were treated with $50 \mathrm{nM}$ oleandrin for 0,24 and $48 \mathrm{~h}$. Total RNA was extracted using TRIzol reagent (Invitrogen, Carlsbad, CA) according to the manufacturer's protocol. Ten micrograms of RNA were reverse transcribed into cDNA using GoScript ${ }^{\mathrm{TM}}$ Reverse Transcription System (Promega, Southampton, UK). The cDNA was added to a $2 \times$ Taq PCR MasterMix (Tiangen Biotech Co., LTD, Beijing, China) containing $10 \mathrm{pmol} / \mathrm{L}$ of each of the corresponding primer pairs. The detailed information of the primers used in this analysis was listed in Table 1. PCR amplification was performed with corresponding cycles of $94{ }^{\circ} \mathrm{C}$ for $3 \mathrm{~min}, 94{ }^{\circ} \mathrm{C}$ for $30 \mathrm{~s}$, at the annealing temperature for $30 \mathrm{~s}, 72{ }^{\circ} \mathrm{C}$ for $1 \mathrm{~min}$ and $72{ }^{\circ} \mathrm{C}$ for $5 \mathrm{~min}$. The PCR products were separated on $1 \%$ agarose gels and were stained with ethidium bromide. The gels were scanned under a gel documentation system (Bio-Rad Co.). $\beta$-actin was used as an internal reference to verify equal concentrations of cDNA in each sample.

\section{Western blot analysis}

For protein expression analysis, U2OS cells were seeded in 100-mm dishes and treated with $50 \mathrm{nM}$ oleandrin for 0,24 and $48 \mathrm{~h}$. Total proteins were extracted by RIPA lysis buffer (Applygen Technologies Inc., Beijing, China). Cell nuclear and cytoplasm proteins were extracted 
Table 1 The details of primers in semi-quantitative RT-PCR

\begin{tabular}{|c|c|c|c|}
\hline Gene & Primer sequence ( $5^{\prime}$ to $\left.3^{\prime}\right)$ & Annealing temperature $\left({ }^{\circ} \mathrm{C}\right)$ & Cycle number \\
\hline \multirow[t]{2}{*}{ c-Myc } & F: CCACACATCAGCACAACTACG & \multirow[t]{2}{*}{57} & \multirow[t]{2}{*}{30} \\
\hline & R: CCGCAACAAGTCCTCTTCAG & & \\
\hline \multirow[t]{2}{*}{ cyclin D1 } & F: TCGGGAGAGGATTAGGTTCC & \multirow[t]{2}{*}{57} & \multirow[t]{2}{*}{30} \\
\hline & R: GTCACTGGATGGTTTGTTGG & & \\
\hline \multirow[t]{2}{*}{ survivin } & F: GTCCCTGGCTCCTCTACTGTT & \multirow[t]{2}{*}{57} & \multirow[t]{2}{*}{30} \\
\hline & R: GATGTGAAGGTTGGGCTGAC & & \\
\hline \multirow[t]{2}{*}{ MMP-2 } & F: GACCACAGCCAACTACGATG & \multirow[t]{2}{*}{59} & \multirow[t]{2}{*}{30} \\
\hline & R: CACAGTCCGCCAAATGAAC & & \\
\hline \multirow[t]{2}{*}{ MMP-9 } & F: CATCGTCATCCAGTITGGTGT & \multirow[t]{2}{*}{57} & \multirow[t]{2}{*}{32} \\
\hline & R: AGGGTTTCCCATCAGCATT & & \\
\hline \multirow[t]{2}{*}{$\beta$-actin } & F: AGCGAGCATCCCCCAAAGTT & \multirow[t]{2}{*}{59} & \multirow[t]{2}{*}{25} \\
\hline & R: GGGCACGAAGGCTCATCATT & & \\
\hline
\end{tabular}

separately using the NE-PER ${ }^{\mathrm{Ts}}$ Nuclear and Cytoplasm Extraction Reagents (Pierce Biotechnology Inc., Rockfold, USA) according to the manufacturer's protocol. The protein concentration was detected using the BCA method. All the samples were mixed with $5 \times$ sodium dodecyl sulfate (SDS) loading buffer (1:4), boiled for $5 \mathrm{~min}$ and stored at $-80{ }^{\circ} \mathrm{C}$ for later use. The same amount of protein was separated on a discontinuous SDS-PAGE gel (8-15\% separation gel) and transferred to a nitrocellulose membrane after electrophoresis. The membranes were blocked with $5 \%$ BSA in TBS containing $0.05 \%$ Tween 20 for $2 \mathrm{~h}$ and were incubated with corresponding rabbit primary antibodies overnight at $4{ }^{\circ} \mathrm{C}$. The antibodies included $\beta$ catenin (1:1000, Santa Cruz Biotechnology, USA), cyclin D1, survivin, c-myc (1:1000, Cell Signaling Technology, Boston, Massachusetts, USA), MMP-9, lamin A/C, $\alpha$-tubulin (1:1000, Abcam, Cambridge, MA, USA) and GAPDH (1:2000, Tiangen Biotech Co., LTD, Beijing, China). Among them, lamin $\mathrm{A} / \mathrm{C}$ and $\alpha$-tubulin were used as internal controls for the nuclear and cytoplasm proteins, respectively. GAPDH were used as an internal control for the total protein. The secondary antibody was an IRDye $800 \mathrm{CW}$ conjugated goat (polyclonal) anti-rabbit IgG secondary antibody (1:10000, LI-COR, Nebraska, USA). The fluorescent bands were visualized with an Odyssey infrared imaging system (LI-COR), and the gray values were analyzed using Odyssey V3.0 software.

\section{Dual luciferase assay}

The dual luciferase assay was performed with the dualluciferase ${ }^{\ominus}$ reporter assay system (Promega Corp., Madison, WI). All reagents were prepared as described by the manufacturer of the TCF Reporter Plasmid Kit (Millipore Corp., MA, USA). After the transfection complex was formed with FOP DNA, pRL-TK Vector renilla (Promega Corp., Madison, WI) and $50 \mu \mathrm{l}$ of DNA Lipofectamine ${ }^{\mathrm{TM}}$ 2000 (Invitrogen, Carlsbad, CA), the cells were seeded into 96-well plates with $100 \mu \mathrm{l} /$ well. U2OS cells were divided into four groups: oleandrin (time): $50 \mathrm{nM}$ oleandrin for 0 , 24 and $48 \mathrm{~h}$; oleandrin (concentration): 0, 25 and $50 \mathrm{nM}$ oleandrin for $24 \mathrm{~h}, \mathrm{LiCl}+$ oleandrin (time) and $\mathrm{LiCl}+$ oleandrin (concentration). For the $\mathrm{LiCl}$ groups, the cells were pretreated with $20 \mathrm{mM} \mathrm{LiCl}$ for $6 \mathrm{~h}$ to activate the Wnt signaling pathway. After the cells were lysed with PLB for $15 \mathrm{~min}$, firefly luciferase reagent LARII $(100 \mu \mathrm{l})$ and Stop \& Glo Reagent $(100 \mu \mathrm{l})$ (Promega Corp., Madison, WI) were added. The OD values of the TOP flash and the FOP flash were detected and the TOP/FOP ratio reflected the activity of the $\mathrm{Wnt} / \beta$-catenin signaling pathway.

\section{Statistical analysis}

The data were presented as the means \pm standard deviation (SD) and were analyzed with PASW statistics 18 software. A value of $P<0.05$ was considered statistically significant. Comparisons of two or more data sets were analyzed using one-way analysis of variance (ANOVA), and data with more than two variables were analyzed using two-way repeated-measures ANOVAs with post hoc Tukey's analysis.

\section{Results}

The viability and proliferation of OS cells were suppressed by oleandrin

The CCK- 8 assay was performed to evaluate the antiproliferative effect of oleandrin on U2OS and SaOS-2 cells. Using various concentrations of oleandrin to treat cells for different times, both cell lines exhibited significantly different viabilities with a decreasing trend of concentration- and time- dependency $(1 \mathrm{a}, \mathrm{b})$. For U2OS, the administration of $25 \mathrm{nM}$ oleandrin decreased the cell viability without a significant difference at $24 \mathrm{~h}(P>0.05)$, but with a significant difference at $48 \mathrm{~h}(P<0.01)$. However, the viability of cells was reduced significantly after treatment with $50 \mathrm{nM}$ oleandrin for $24 \mathrm{~h}(P<0.01)$ and $48 \mathrm{~h}(P<0.01)$. Subsequently, 

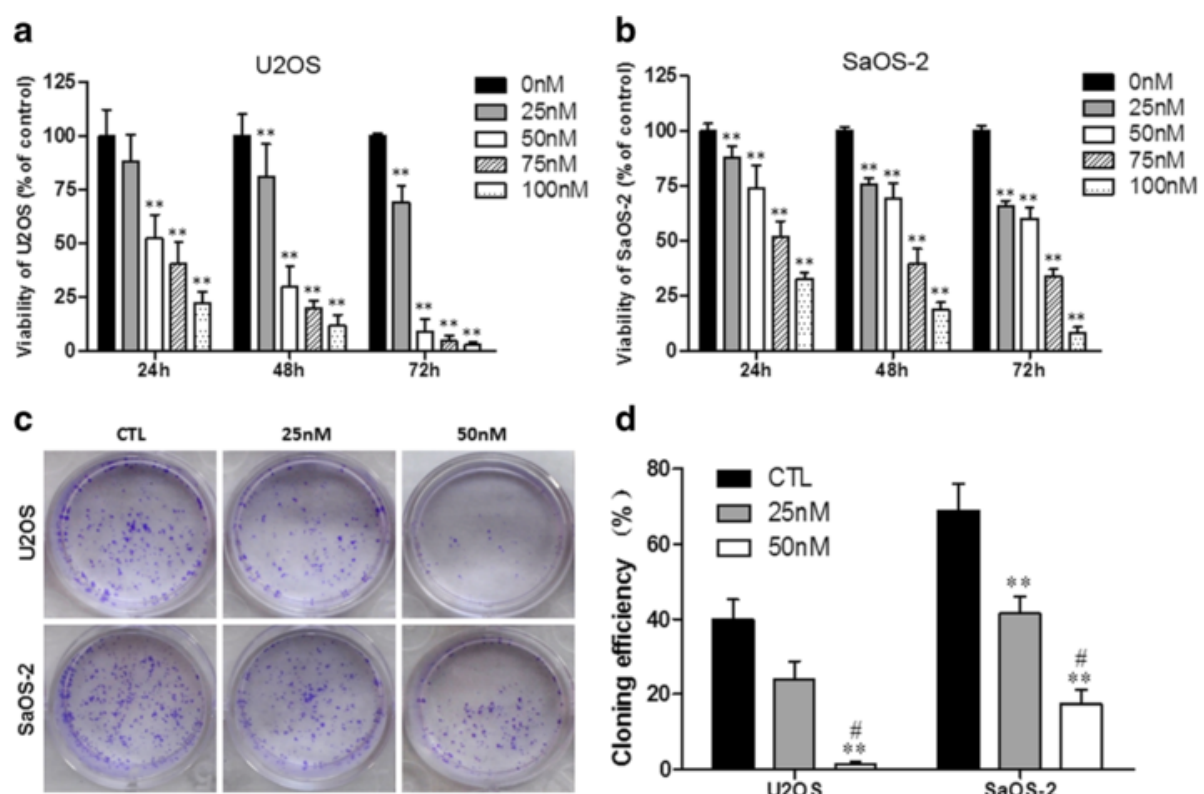

d

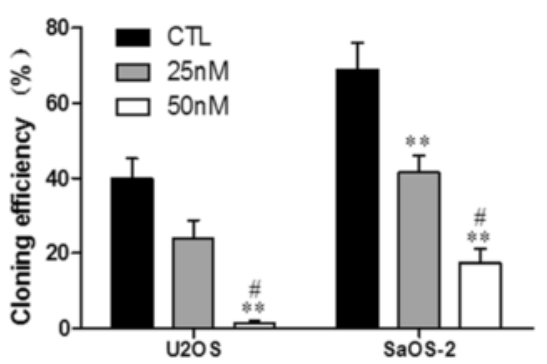

Fig. 1 The inhibiting effect of oleandrin on OS cell proliferation. $\mathbf{a} / \mathbf{b}$ The viability of U2OS (a) and SaOS-2 (b) cells after treatment with various concentrations of oleandrin for varying times. $\mathbf{c}$ A macrograph of the clone formation of the U2OS and SaOS-2 cells. d Cloning efficiency (\%) of U2OS and SaOS-2 cells. $n=3$. Mean \pm SD. ${ }^{* *} P<0.01$, vs. control group $(C T L) .{ }^{\#} P<0.05$, vs. $25 n M$

only a few cells remained at $72 \mathrm{~h}$ post-treatment. For SaOS-2, however, both $25 \mathrm{nM}$ and $50 \mathrm{nM}$ oleandrin significantly decreased cell viability after treatment for $24 \mathrm{~h}(P<$ $0.01)$ and $48 \mathrm{~h}(P<0.01)$. Based on these results, we selected $25 \mathrm{nM}$ or $50 \mathrm{nM}$ oleandrin to treat the cells for $24 \mathrm{~h}$ and $50 \mathrm{nM}$ oleandrin to treat cells for $24 \mathrm{~h}$ or $48 \mathrm{~h}$ in the following experiments.

The influence of oleandrin on the colony forming abilities of OS cells was also observed by performing plate clone formation assays. Both U2OS and SaOS-2 cells were isolated separately and cloned as described in the Methods section. After treatment with $25 \mathrm{nM}$ and $50 \mathrm{nM}$ oleandrin for $24 \mathrm{~h}$, the U2OS and SaOS-2 colonies were significantly reduced (Fig. 1c). The cloning efficiencies of U2OS at 25 $\mathrm{nM}$ and $50 \mathrm{nM}$ compared with the control were $24.0 \%$ and $1.5 \%$ vs. $39.8 \%(25 \mathrm{nM}$ or $50 \mathrm{nM}$ vs. control: $P=$ 0.207 or $P=0.002$; 25 nM vs. 50 nM: $P=0.019$ ), respectively (Fig. 1d). Correspondingly, the cloning efficiencies of SaOS- 2 at $25 \mathrm{nM}$ and $50 \mathrm{nM}$ compared with the control were $41.5 \%$ and $17.5 \%$ vs. $69.0 \%$ (25 nM or $50 \mathrm{nM}$ vs. control: $P=0.005$ or $P=0.000 ; 25$ nM vs. 50 nM: $P=$ 0.011), respectively (Fig. 1d).

\section{The morphology of OS cells was changed by oleandrin treatment}

After treatment with $25 \mathrm{nM}$ and $50 \mathrm{nM}$ oleandrin for $24 \mathrm{~h}$, U2OS and SaOS-2 cells were observed by an optical microscope at a low magnification $(50 \times)$ to a high magnification (100x and 200x). After exposure to oleandrin, the number of $\mathrm{U} 2 \mathrm{OS}$ and SaOS-2 cells gradually reduced at low magnification. At high magnification, we also observed that both cell lines presented typical apoptotic morphological changes, which included the irregularities in the cell surfaces and the vesicles in the cytoplasm after exposure to 25 $\mathrm{nM}$ and $50 \mathrm{nM}$ oleandrin (Fig. 2a, b).

\section{Oleandrin induced OS cells apoptosis}

Dye 4'-6-diamidino-2-phenylindole (DAPI) staining is a classic method to reflect the morphological changes of the cell nucleus in apoptosis. Fig. 2c shows that without oleandrin, the cell nuclei of U2OS and SaOS-2 cells are dispersed uniformly. However, after exposure to the drug, many OS cell nuclei became pyknotic and underwent karorrhexis and karyolysis.

Next, we detected FCM apoptosis following Annexin VFITC and PI double staining to confirm this phenomenon. After treatment with $50 \mathrm{nM}$ of oleandrin, the total number of apoptosed cells in both the U2OS and SaOS- 2 cell lines increased significantly (Fig. 3a, b). The apoptosis rates of U2OS cells at 0,24 and $48 \mathrm{~h}$ were $15.8 \%, 29.0 \%$ and $46.0 \%$, respectively ( 24 or 48 vs. 0 h: $P=0.005$ or $P$ $=0.000 ; 24$ vs. 48 h: $P=0.001$ ) (Fig. 3c). Similarly, the apoptosis rates of the SaOS-2 cells were $10.6 \%, 22.2 \%$ and $31.8 \%$, respectively ( 24 or 48 vs. 0 h: $P=0.007$ or $P=$ 0.000 ; 24 vs. 48 h: $P=0.015$ ) (Fig. $3 d$ ).

\section{Oleandrin suppressed the migration and invasion of U2OS and SaOS- 2 cells}

Given the cytotoxic activity of oleandrin at high concentrations, we used a low concentration $(25 \mathrm{nM})$ to evaluate 


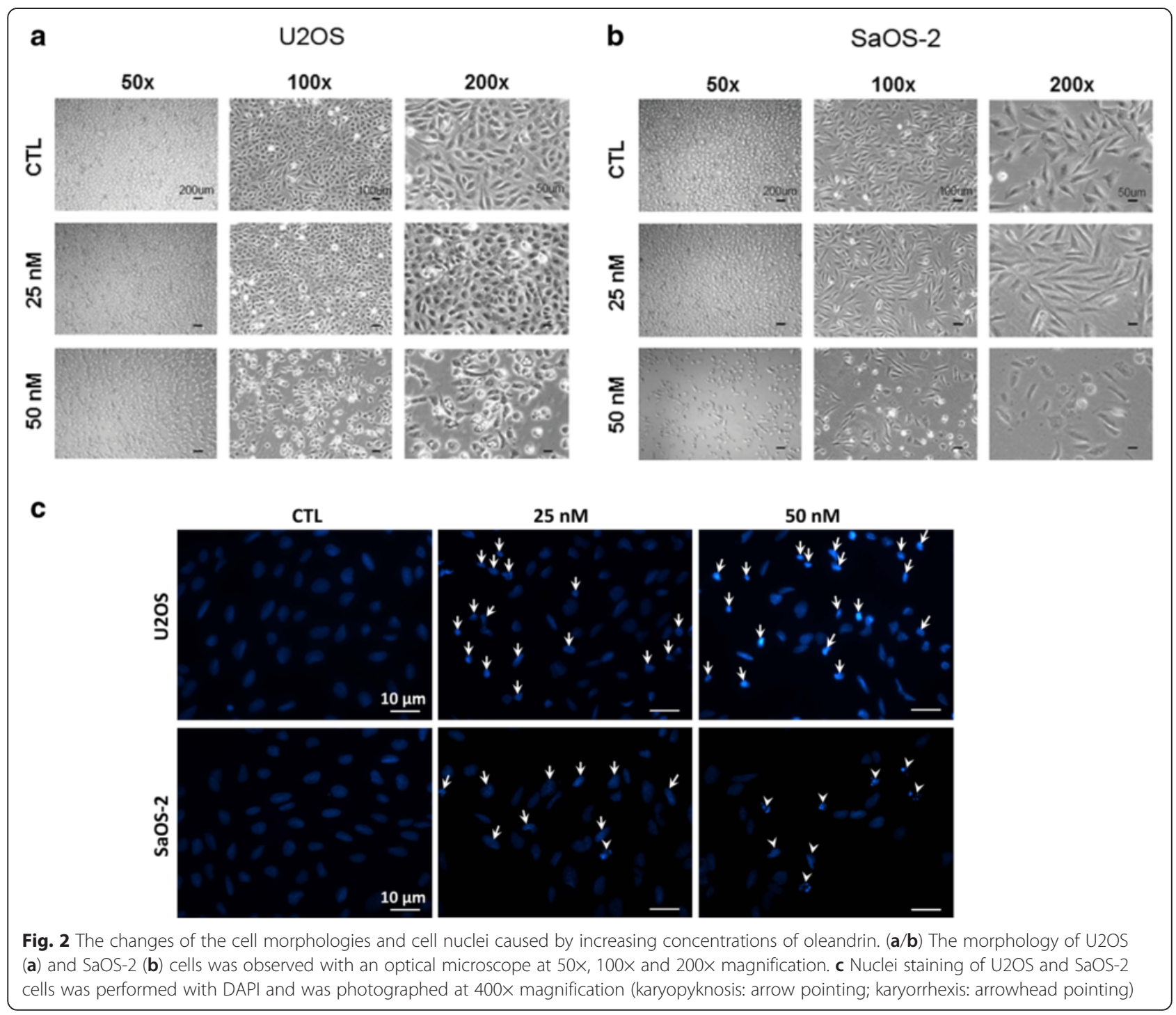

the effect of oleandrin on cell migration and invasion in vitro with wound healing and transwell invasion assays, respectively. In our pre-experiments, the migration rate of U2OS was greater than that of SaOS-2, and after treatment with oleandrin for nearly $48 \mathrm{~h}$, the scratches in the control of the U2OS cell line had already closed while the scratches in the control of the SaOS-2 cell line had not (data not shown). Therefore, we selected the treatment length for $\mathrm{U} 2 \mathrm{OS}$ to be 6,12 and $24 \mathrm{~h}$ and the treatment length for SaOS-2 to be 24, 48 and $72 \mathrm{~h}$. The results showed that with an increased treatment time, the migration capabilities of both cell lines were suppressed (Fig. 4a, b). The ratio of the distance migrated in the control group compared with the $25 \mathrm{nM}$ oleandrin group in U2OS cells at 6, 12 and $24 \mathrm{~h}$ was $16.6 \%$ vs. $12.6 \%(P=0.482), 28.2 \%$ vs. $22.4 \%(P=0.213)$ and $39.3 \%$ vs. $17.1 \%(P=0.003)$, respectively (Fig. $4 \mathrm{c})$. Meanwhile, in the SaOS-2 cells, the corresponding results at 24,48 and $72 \mathrm{~h}$ were $31.4 \%$ vs. $18.5 \%(P=0.023), 43.8$
\% vs. $21.9 \%(P=0.000)$ and $54.7 \%$ vs. $24.8 \%(P=0.000)$, respectively (Fig. 4d).

Consistent with the wound healing assay, the results of the transwell invasion assay indicated that OS cells that invaded from the Matrigel into the substratum of the membrane were significantly decreased after treatment (Fig. 4e). The numbers in the substratum of the membrane per view under high magnification $(200 \times)$ in the control group compared with the $25 \mathrm{nM}$ oleandrin group of U2OS cells were $41.1 \pm 5.7$ vs. $25.8 \pm 6.1 \quad(P=0.033)$, and the corresponding numbers of SaOS-2 cells were $65.8 \pm 12.3$ vs. $39.4 \pm 10.0(P=0.045)$ (Fig. $4 f)$.

\section{Oleandrin suppressed the activity of $\mathrm{Wnt} / \beta$-catenin signaling pathway}

Previous studies reported that the abnormal activation of the Wnt signaling pathway plays an important role in OS pathogenesis. In this study, we explored whether 


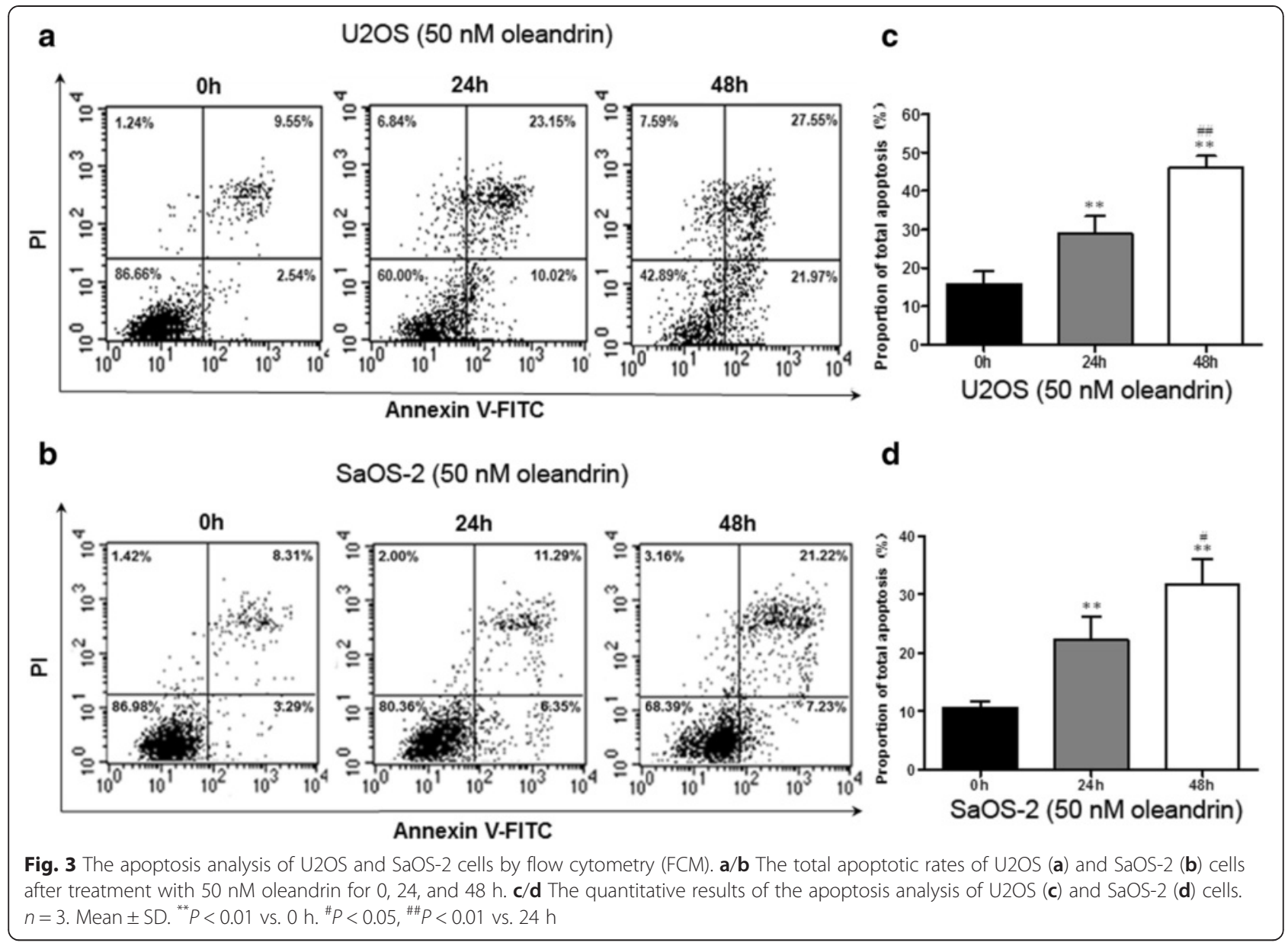

oleandrin had an effect on the Wnt/B-catenin signaling pathway, and a dual-luciferase assay was used to evaluate this effect in U2OS cells. Fig. 5a shows that without $\mathrm{LiCl}$, an inhibitor of GSK-3 $\beta$, oleandrin was able to suppress the activities of $\mathrm{Wnt} / \beta$-catenin signaling by downregulating the TOP/FOP flash ratio in a concentration-dependent manner ( $25 \mathrm{nM}$ or $50 \mathrm{nM}$ vs. control: $P=0.017$ or $P=$ $0.001,25 \mathrm{nM}$ vs. $50 \mathrm{nM}: P=0.043)$. In addition, after pretreatment with $\mathrm{LiCl}$, the TOP/FOP flash ratio first increased but then declined in a concentration-dependent manner after oleandrin treatment $(25 \mathrm{nM}$ or $50 \mathrm{nM}$ vs. control: $P=0.073$ or $P=0.005,25 \mathrm{nM}$ vs. $50 \mathrm{nM}: P=$ 0.070). Similarly, Fig. $5 \mathrm{~b}$ also shows that oleandrin could downregulate the TOP/FOP flash ratio in a time-dependent manner with $\mathrm{LiCl}$ ( 24 or 48 h vs. 0 h: $P=0.004$ or $P=$ $0.000,24$ vs. $48 \mathrm{~h}: P=0.005$ ) or without $\mathrm{LiCl}(24$ or 48 vs. 0 h: $P=0.017$ or $P=0.002$, 24 vs. 48 h: $P=0.120$ ).

\section{Oleandrin downregulated the target gene expression of the Wnt/B-catenin pathway at both the mRNA and protein levels}

To study the effect of oleandrin on the $\mathrm{Wnt} / \beta$-catenin signaling pathway, we detected the mRNA and total protein expression changes of the downstream target genes, which included c-myc, survivin, cyclin D1, MMP2 and MMP-9, using semi-quantitative RT-PCR and western blot assays. As we expected, the results of the RT-PCR showed that oleandrin significantly downregulated the mRNA levels of these genes to different degrees dependent on treatment time (Fig. 5c, d). In accordance with the RT-PCR results, after treatment with oleandrin for 24 and $48 \mathrm{~h}$, the protein expression of the target genes was reduced, which indicated that oleandrin had a remarkable inhibiting effect on the downstream molecules of the Wnt/ $\beta$-catenin signaling pathway (Fig. 6a, b).

\section{Oleandrin inhibited the protein expression of $\beta$-catenin and reduced its nuclear localization}

As a key transcriptional factor, the expression and nuclear accumulation of $\beta$-catenin directly influenced the activity of the Wnt signaling pathway and regulated the transcription and expression of the target genes. Therefore, we explored the regulating effect of oleandrin on $\beta$-catenin by western blot analysis of the total cytoplasmic and nuclear protein extracts. As shown in Fig. 6c, d, oleandrin treatment led to significantly decreased total 


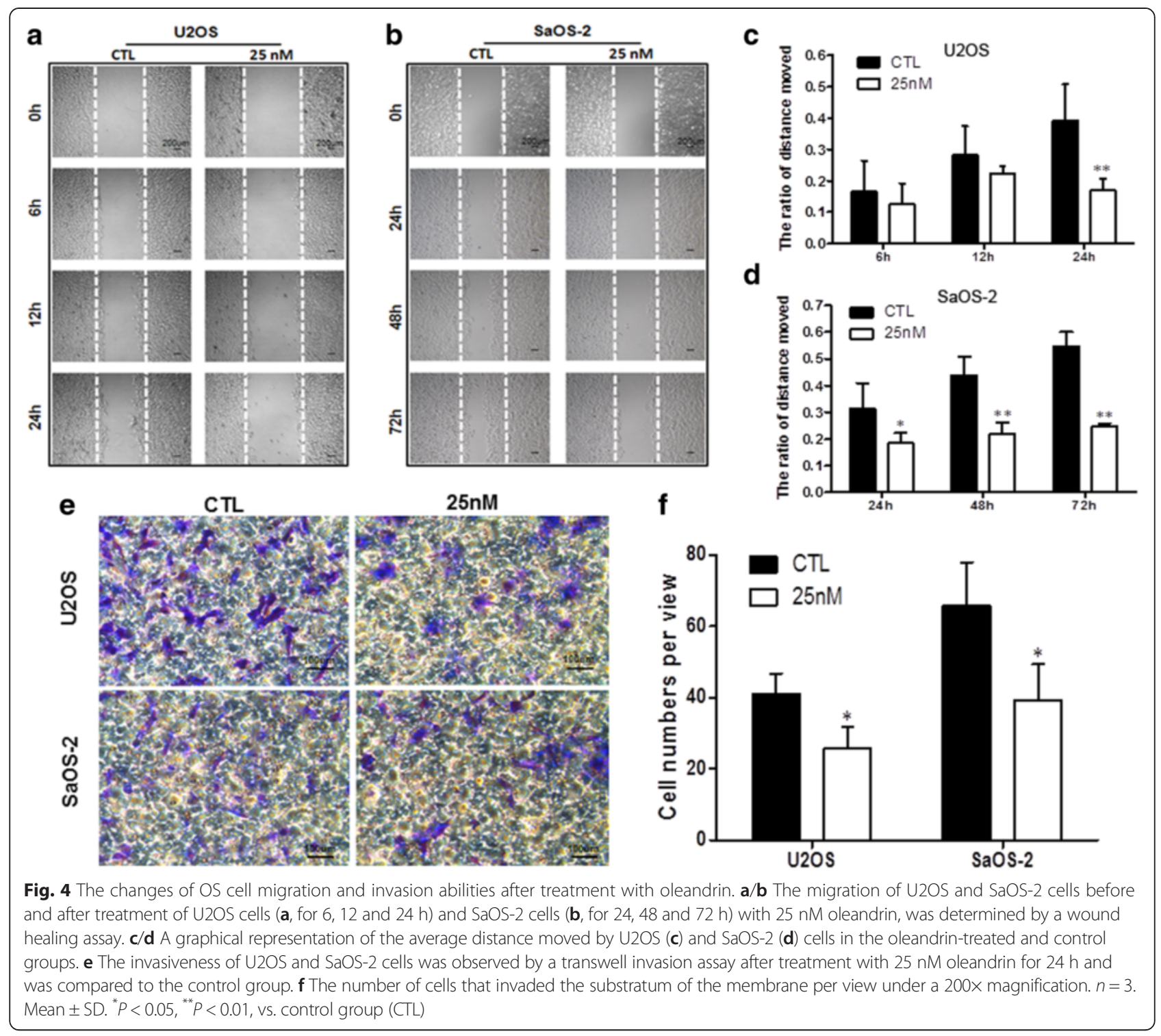

$\beta$-catenin levels over time. According to the nuclear and cytoplasmic protein expression results, we found that $\beta$-catenin was located in the cytoplasm as well as in the nucleus of the control. Nevertheless, after treatment with $50 \mathrm{nM}$ of oleandrin, the $\beta$-catenin located in nucleus was gradually decreased, and the difference became very evident $(P<0.01)$ after $48 \mathrm{~h}$ of treatment. There was a slight decreasing trend in the levels of cytoplamic $\beta$-catenin, but no significant difference was observed.

\section{Effects of oleandrin on the MMP-2 and MMP-9 activities of human OS cells}

Gelatin zymography is a simple yet powerful method to detect proteolytic enzymes that are capable of degrading gelatin from various biological sources. It is particularly useful for the assessment of two key members of the matrix metalloproteinase family, MMP-2 and MMP-9 $[18,19]$. We used this method to further explore the change of MMP-2 and MMP-9 activities in U2OS cells. With the treatment of $25 \mathrm{nM}$ and $50 \mathrm{nM}$ of oleandrin for $24 \mathrm{~h}$, the ability of MMP-2 and MMP-9 to degrade gelatins was significantly reduced (Fig. 6e).

\section{Discussion}

Osteosarcoma is the most frequent malignant bone tumor and is derived from primitive bone-forming mesenchymal cells with a high propensity for neovascularization and distant metastasis [20], which could seriously threaten the patients' life.

Recently, oleandrin has been used as a novel drug to treat malignant tumors due to its selectively tumorkilling and radio-chemotherapy sensitization effects. Newman et al. [5] reported that oleandrin had a potent 

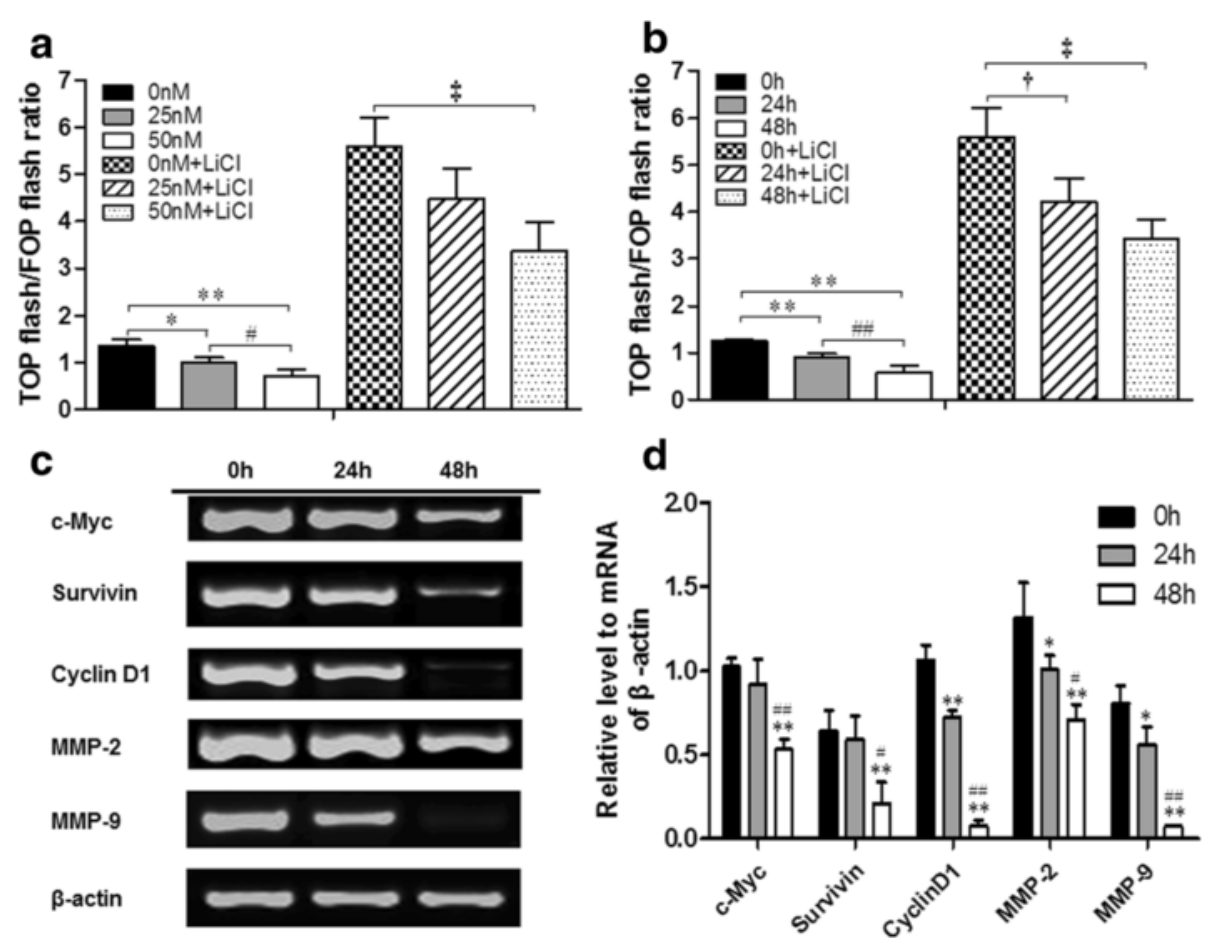

Fig. 5 Changes in the Wnt/ $\beta$-catenin signaling activities of U2OS and the mRNA expression levels of related downstream genes in this pathway. $(\mathbf{a} / \mathbf{b})$ With or without pretreatment with $20 \mu \mathrm{M} \mathrm{LiCl}$, the TOP/FOP flash ratios were detected using a dual-luciferase assay in U2OS cells after treatment with 0,25 and $50 \mathrm{nM}$ of oleandrin for $24 \mathrm{~h} \mathrm{(a),} \mathrm{or} 50 \mathrm{nM}$ of oleandrin for 0,24 and $48 \mathrm{~h}(\mathbf{b})$, respectively. $n=3, \mathrm{Mean} \pm \mathrm{SD}$. ${ }^{*} P<0.05{ }^{* *} P<0.01$, compared to the control group without $\mathrm{LiCl}$ in each intervention condition ( $0 \mathrm{nM}$ group or 0 h group); ${ }^{~} P<0.05$, ${ }^{\# \#} P<0.01$, in the absence of LiCl, $25 \mathrm{nM}$ group v.s. $50 \mathrm{nM}$ group, $24 \mathrm{~h}$ group vs. $48 \mathrm{~h}$ group; ${ }^{\dagger} P<0.05,{ }^{\ddagger} p<0.01$, compared to the control group with LiCl in each intervention condition (0 nM group or 0 h group). c The gel electrophoresis of c-myc, survivin, cyclin D1, MMP-2, MMP-9 and $\beta$-actin after amplification. $\mathbf{d}$ The semi-quantitative relationship between the mRNA expression levels of related target genes and $\beta$-actin in U2OS cells according to the results of gel electrophoresis in RT-PCR after treatment with 50 nM of oleandrin for 0,24 and 48 h. ${ }^{*} P<0.05,{ }^{* *} P<0.01$, compared to the 0 h group. ${ }^{\#} P<0.05,{ }^{\# \#} P<0.01$, compared to the 24 h group

cytotoxicity to human melanoma cells and induced cells apoptosis. Manna et al. [21] reported that oleandrin could suppress the activation of nuclear transcription factor- $\mathrm{k}$ (NF- $\mathrm{kB})$, activator protein-1 (AP-1), and c-Jun $\mathrm{NH}_{2}$-terminal kinase. NF- $\mathrm{BB}$ and $\mathrm{AP}-1$ are known to play major roles in cell proliferation, tumor promotion, and drug resistance [22]. Boulares et al. [23] also indicated that oleandrin could activate NF- $\mathrm{kB}$ in different cell types and induce apoptosis by caspase-dependent PARP cleavage and DNA fragmentation. The study of McConkey et al. [11] demonstrated that oleandrin treatment led to the apoptosis of prostate tumor cells, and this effect is mediated through the inhibition of $\mathrm{Na}^{+}$, $\mathrm{K}^{+}$-ATPase. Moreover, Frese et al. [7] found that oleandrin could enhance the pro-apoptotic sensibility of non-small cell lung cancer, which is induced by Apo2L/TRAIL through the upregulation of the death receptors 4 and 5 . In this study, we explored the effect of oleandrin on OS cells and the related mechanisms.

First, the influence of oleandrin on the viability and proliferation of OS cells were determined by CCK- 8 and clone formation assays. Our results showed that oleandrin treatment reduced the viability of U2OS and SaOS-2 cells in a time- and concentration-dependent manner and decreased the cell cloning efficiencies. Under a light microscope, we also observed that following treatment with 25 $\mathrm{nM}$ and $50 \mathrm{nM}$ of oleandrin for $24 \mathrm{~h}$, the cell surfaces were irregular and vesicles existed in the cytoplasm, which are typical apoptotic morphological changes [24]. Therefore, we concluded that oleandrin could inhibit the proliferation of OS cells and induce their apoptosis, which was also confirmed by DAPI staining and FCM. DAPI staining showed that oleandrin treatment led to the nuclei of OS cells presenting with pyknotic, karorrhexis and even karyolysis characteristics, while the cell nuclei in the control group were uniformly dispersed. FCM also indicated that the total apoptosis rates of both OS cells were increased significantly with treatment time. All of these findings indicate that oleandrin can dramatically induce OS cell apoptosis, which is consistent with previous studies that reported the apoptosis-induction effect of oleandrin on other tumor cells [25]. Cell migration is a tightly regulated process that occurs in tissue development and underlies pathological conditions, such as cancer invasion, and cell invasiveness, which is a crucial process of cancer metastasis $[26,27]$. We also observed the effect of oleandrin on 


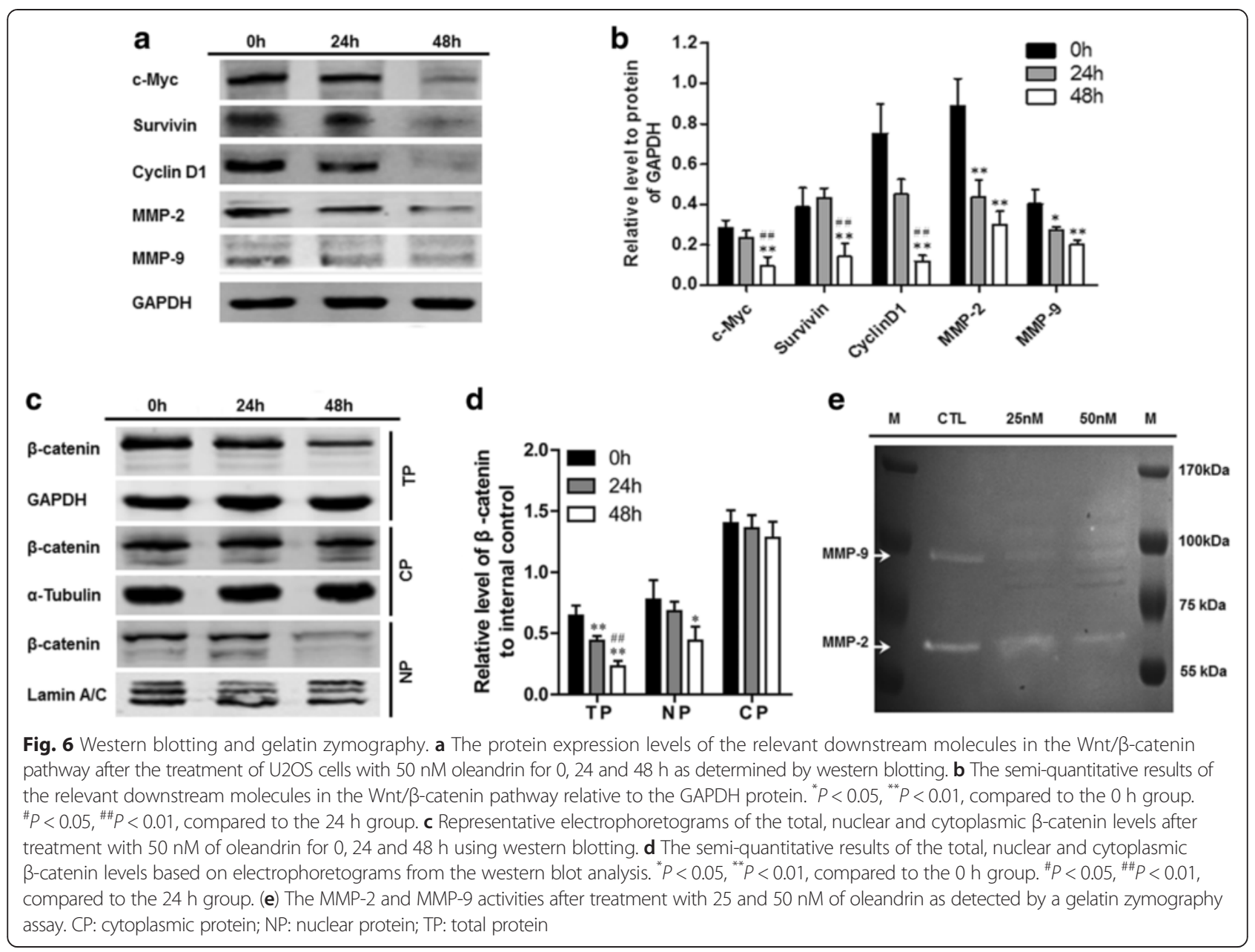

the migration and invasion of U2OS and SaOS-2 cell lines by using a wound healing assay and a transwell invasion assay. The results showed that the migration rates of both cell lines were inhibited and that the number of OS cells that moved from the Matrigel into the substratum of the membrane was significantly decreased by oleandrin application. These results support that oleandrin can not only suppress the migration of OS cells but also inhibit their invasion capacities.

Previous studies had reported that the activation of the Wnt/ $\beta$-catenin signaling pathway was widely apparent in OS tissue/cells and that its aberrant activation played a significant role in OS tumorigenesis, metastasis and chemotherapeutic responses [28, 29]. In this study, we explored whether oleandrin had an effect on the Wnt/ $\beta$-catenin signaling pathway, and the dual-luciferase reporter assay with the TOP/FOP flash plasmid system was used to evaluate this mechanism in U2OS cells. The TOP/FOP flash plasmid system is the most common method and has been used by many previous studies to evaluate the transcriptional activity of TCF/LEF in Wnt/B-catenin signaling [30]. In this study, we detected the values of the TOP flash and the FOP flash of OS cells under oleandrin treatment with or without $\mathrm{LiCl}$, an inhibitor of GSK-3 $\beta$. Additionally, the TOP/FOP flash ratio was presented to reflect the activity of $\mathrm{Wnt} / \beta$ catenin signaling. The results demonstrate that the TOP/ FOP flash ratio dramatically decreased in a time- and concentration-dependent manner, which demonstrates that the transcriptional activity of TCF/LEF was suppressed by oleandrin. Even after the Wnt/ $\beta$-catenin signaling in OS cells was pre-activated by $\mathrm{LiCl}$, the TOP/FOP flash ratio still declined in a time- and concentration-dependent fashion after exposure to oleandrin. Thus, we speculated that oleandrin may suppress the activity of the Wnt/ $\beta$-catenin signaling pathway and further influence the downstream genes of this pathway, such as c-myc, cyclin D1, survivin and matrix metalloproteinases (MMPs) [31].

c-Myc is a helix-loop-helix leucine zipper phosphoprotein that regulates gene transcription in cell proliferation, cell differentiation, and programmed cell death [32]. Its overexpression is one of the most common alterations in human cancers. Reports also show that the suppression of 
c-myc oncogene induces cellular senescence in diverse tumor types, including OS [31]. Survivin is an inhibitor of the apoptosis protein and a key determinant in protecting cells from apoptosis. It is over-expressed in most tumors, such as OS. It displays a significant function on the development of OS and could be taken as a prognostic factor for OS patients [33, 34]. Cyclin D1 is a key regulator of the G1 phase of the cell cycle [35]. It is overexpressed in many cancers, including OS, and regulates cell proliferation through the activation of cyclin-dependent kinases [36]. MMP-2 and MMP-9 are enzymes that are implicated in the malignant progression of many tumor types. They play a vital role in tumor invasion and angiogenesis [37] and are believed to be a critical part of the invasive potential of tumor cells because of their ability to degrade type IV collagen, a major structural component of basement membranes [38]. In OS patients, the overexpression of MMP-2 and MMP-9 is always observed [39].

The mRNA and protein expression of the downstream genes of the $\mathrm{Wnt} / \beta$-catenin pathway including $\mathrm{c}$-myc, cyclin D1, survivin, MMP-2 and MMP-9 were detected using semi-quantitative RT-PCR and western blot assays. As expected, both assays indicated that oleandrin, at varying treatment lengths, could significantly downregulate the mRNA levels and protein expression of these genes. We already knew that oleandrin inhibited the migration and invasion of OS cells through influencing the expression of MMP-2 and MMP-9. Subsequently, we further explored the change of MMP-2 and MMP-9 activities with gelatin zymography. With the treatment of $25 \mathrm{nM}$ and $50 \mathrm{nM}$ oleandrin for $24 \mathrm{~h}$, the MMP-2 and MMP-9 activities were reduced. These findings demonstrate that oleandrin not only inhibits the expression of MMP-2 and MMP-9 but also suppresses their enzyme activities. Therefore, based on the reports above, we concluded that oleandrin suppressed the Wnt/ $\beta$-catenin signaling pathway by downregulating the expression of the target genes and also inhibited the enzyme activities of MMP-2 and MMP-9.

$\beta$-Catenin is a key molecule in the $\mathrm{Wnt} / \beta$-catenin signaling pathway, and its shuttling in osteosarcoma cells between the cytoplasm and the nucleus is a common phenomenon in terms of the activation state of the Wnt/ $\beta$-catenin pathway [40]. In the nucleus, $\beta$-catenin interacts with TCF/LEF and triggers the transcription of target genes. Therefore, nuclear $\beta$-catenin accumulation is a key event in the activation of $\mathrm{Wnt} / \beta$-catenin signaling. The deregulation of the $\mathrm{Wnt} / \beta$-catenin pathway would result in the aberrant accumulation of $\beta$-catenin in the nucleus, which occurs in parallel to the development of cancer [41]. In this study, we found that the levels of total and nuclear $\beta$-catenin were significantly decreased in response to varying treatment lengths. Although there was a slight decreasing trend in the levels cytoplasmic $\beta$-catenin, no significant difference was observed. These results indicate that oleandrin treatment could effectively reduce the nuclear location of $\beta$ catenin. To a certain degree, our findings are consistent with those of previous studies, which have reported that the suppression of the $\mathrm{Wnt} / \beta$-catenin signaling pathway would lead to the reduction of nuclear $\beta$-catenin [42]. Our results further demonstrated that oleandrin could suppress the activity of the $\mathrm{Wnt} / \beta$-catenin signaling pathway.

Of course, there were limitations to this study. We only explored the antitumor effect and underlying mechanism of oleandrin on two human OS cell lines in vitro. Hence, in our further studies, we will investigate the antitumor effect of oleandrin in animal models and we will study the detailed mechanisms of the invasion inhibition and apoptosis-inducing effects of oleandrin in vivo.

\section{Conclusions}

In conclusion, we found that oleandrin, in vitro, could inhibit proliferation, induce apoptosis and reduce the invasiveness of U2OS and SaOS-2 cells. The antitumor activities of oleandrin on OS cells were probably achieved by suppressing the $\mathrm{Wnt} / \beta$-catenin signaling pathway, which resulted in the down-regulation of target genes and decreased the total and nuclear $\beta$ catenin. In addition, oleandrin not only reduced MMP-2 and MMP-9 expression but also suppressed their activities.

\section{Abbreviations}

OS: Osteosarcoma; TCF/LEF: T-cell factor/lymphocyte enhancer factor; MMPs: Matrix metalloproteinase; DAPI: Dye 4'-6-diamidino-2-phenylindole; NF-kB: Nuclear transcription factor-kB; AP-1: Activator protein-1; GSK $3 \beta$ : Glycogen synthase kinase $3 \beta$; APC: Adenomatous polyposis coli; Fz: Frizzled; LRP5/6: Lipoprotein receptors 5/6; Dsh: Disheveled; FCM: Flow cytometry; PI: Propidium iodide; SD: Standard deviation; ANOVA: Analysis of variance.

\section{Competing interests}

The authors declare that they have no competing interests.

\section{Authors' contributions}

$X G L, Y L M$ conceived of the study, and participated in its design and made sure of integrity of the entire study; YLM, BZ, HLY and LY participated in acquisition of data, or analysis and helped to draft the manuscript; XL and JS were responsible for interpretation of data and literature research; XGL and ZJL involved in coordination and helped to revise the manuscript critically for important intellectual content; All authors read and approved the final manuscript.

\section{Acknowledgements}

This study was financially supported by the National Natural Science Foundation of China (81472041). Thanks to Peking University Third Hospital Central Laboratory for the cells donation and the technical guidance. Thanks to the assistance of Dr. Wang Jun from Department of Orthopedics, Beijing Ji Shui Tan Hospital, Dr. Zhang Wei from Department of Hematology, Peking University Third Hospital and Dr. Zhu Min from Beijing Cancer Hospital in China. We are grateful for the precious suggestions about revising the manuscript of Dr. Huang Chen from the Central Laboratory of Peking University Third Hospital. 
Received: 6 July 2015 Accepted: 30 September 2015

Published online: 06 October 2015

\section{References}

1. Benjamin RS. Osteosarcoma: better treatment through better trial design Lancet Oncol. 2015;16:12-3.

2. Walkley CR, Qudsi R, Sankaran VG, Perry JA, Gostissa M, Roth SI, et al. Conditional mouse osteosarcoma, dependent on p53 loss and potentiated by loss of Rb, mimics the human disease. Genes Develop. 2008;22:1662-76.

3. Tan ML, Choong PF, Dass CR. Osteosarcoma-conventional treatment vs. gene therapy. Cancer Biol Ther. 2009;8:106-17.

4. Chou AJ, Gorlick R. Chemotherapy resistance in osteosarcoma: current challenges and future directions. Expert Rev Anticancer Ther. 2006;6:1075-85.

5. Newman RA, Yang P, Hittelman WN, Lu T, Ho DH, Ni D, et al. Oleandrin-mediated oxidative stress in human melanoma cells. J Exp Ther Oncol. 2006;5:167-81.

6. Stenkvist B. Is digitalis a therapy for breast carcinoma? Oncol Rep. 1999;6:493-9.

7. Frese S, Frese-Schaper M, Andres A-C, Miescher D, Zumkehr B, Schmid RA. Cardiac glycosides initiate Apo2L/trail-induced apoptosis in non-small cell lung cancer cells by up-regulation of death receptors 4 and 5. Cancer Res. 2006;66:5867-74.

8. Raghavendra PB, Sreenivasan Y, Manna SK. Oleandrin induces apoptosis in human, but not in murine cells: dephosphorylation of Akt, expression of FasL, and alteration of membrane fluidity. Mol Immunol. 2007;44:2292-302.

9. Mekhail T, Kaur H, Ganapathi R, Budd GT, Elson P, Bukowski RM. Phase 1 trial of Anvirzel ${ }^{\mathrm{TM}}$ in patients with refractory solid tumors. Invest New Drug. 2006;24:423-7.

10. Yang $P$, Menter DG, Cartwright $C$, Chan D, Dixon S, Suraokar M, et al. Oleandrin-mediated inhibition of human tumor cell proliferation: Importance of $\mathrm{Na}$, K-ATPase a subunits as drug targets. Mol Cancer Ther. 2009;8:2319-28

11. McConkey DJ, Lin Y, Nutt LK, Ozel HZ, Newman RA. Cardiac glycosides stimulate $\mathrm{Ca} 2+$ increases and apoptosis in androgen-independent, metastatic human prostate adenocarcinoma cells. Cancer Res. 2000;60:3807-12.

12. Smith JA, Madden T, Vijjeswarapu M, Newman RA. Inhibition of export of fibroblast growth factor-2 (FGF-2) from the prostate cancer cell lines PC3 and DU145 by Anvirzel and its cardiac glycoside component, oleandrin. Biochem Pharmacol. 2001;62:469-72.

13. Cai Y, Cai T, Chen Y. Wnt pathway in osteosarcoma, from oncogenic to therapeutic. J Cell Biochem. 2014;115:625-31.

14. Zhao S, Wang J, Qin C. Blockade of CXCL12/CXCR4 signaling inhibits intrahepatic cholangiocarcinoma progression and metastasis via inactivation of canonical Wnt pathway. J Exp Clin Canc Res. 2014;33:1-12.

15. Bienz M. The subcellular destinations of APC proteins. Nat Rev Mol Cell Biol. 2002;3:328-38.

16. Cong F, Varmus H. Nuclear-cytoplasmic shuttling of Axin regulates subcellular localization of $\beta$-catenin. Proc Natl Acad Sci U S A. 2004;101:2882-7.

17. He T-C, Sparks AB, Rago C, Hermeking H, Zawel L, da Costa LT, et al. Identification of c-MYC as a target of the APC pathway. Science. 1998;281:1509-12.

18. Toth M, Sohail A, Fridman R. Assessment of gelatinases (MMP-2 and MMP-9) by gelatin zymography. Metastas Res Protoc. 2012;878:121-35.

19. Zhang $H$, Teng $X$, Liu Z, Zhang L, Liu Z. Gene expression profile analyze the molecular mechanism of CXCR7 regulating papillary thyroid carcinoma growth and metastasis. J Exp Clin Canc Res. 2015;34:16.

20. Cai X-S, Jia Y-W, Mei J, Tang R-Y. Tumor blood vessels formation in osteosarcoma: vasculogenesis mimicry. Chin Med J. 2004;117:94-8.

21. Manna SK, Sah NK, Newman RA, Cisneros A, Aggarwal BB. Oleandrin suppresses activation of nuclear transcription factor-KB, activator protein-1, and c-Jun NH2-terminal kinase. Cancer Res. 2000;60:3838-47.

22. Biswas DK, Shi Q, Baily S, Strickland I, Ghosh S, Pardee AB, et al. NF-KB activation in human breast cancer specimens and its role in cell proliferation and apoptosis. Proc Natl Acad Sci U S A. 2004;101:10137-42.

23. Boulares AH, Zoltoski AJ, Yakovlev A, Xu M, Smulson ME. Roles of DNA fragmentation factor and poly (ADP-ribose) polymerase in an amplification phase of tumor necrosis factor-induced apoptosis. J Biol Chem. 2001;276:38185-92.

24. Inbal B, Bialik S, Sabanay I, Shani G, Kimchi A. DAP kinase and DRP-1 mediate membrane blebbing and the formation of autophagic vesicles during programmed cell death. J Cell Biol. 2002;157:455-68.
25. Sreenivasan Y, Raghavendra PB, Manna SKRETRACTEDARTICLE. OleandrinMediated Expression of Fas Potentiates Apoptosis in Tumor Cells. J Clin Immunol. 2006;26:308-22.

26. Friedl P, Wolf K. Plasticity of cell migration: a multiscale tuning model. J Cell Biol. 2010;188:11-9.

27. Eustace BK, Sakurai T, Stewart JK, Yimlamai D, Unger C, Zehetmeier C, et al, Functional proteomic screens reveal an essential extracellular role for hsp90a in cancer cell invasiveness. Nat Cell Biol. 2004;6:507-14.

28. Cai Y, Mohseny AB, Karperien M, Hogendoorn PC, Zhou G, Cleton-Jansen AM. Inactive Wnt/ $\beta$-catenin pathway in conventional high-grade osteosarcoma. J Pathol. 2010;220:24-33.

29. Hendrix ND, Wu R, Kuick R, Schwartz DR, Fearon ER, Cho KR. Fibroblast growth factor 9 has oncogenic activity and is a downstream target of Wht signaling in ovarian endometrioid adenocarcinomas. Cancer Res. 2006;66:1354-62

30. Gao Z, Xu Z, Hung M-S, Lin Y-C, Wang T, Gong M, et al. Promoter demethylation of WIF-1 by epigallocatechin-3-gallate in lung cancer cells. Anticancer Res. 2009;29:2025-30.

31. Wu C-H, van Riggelen J, Yetil A, Fan AC, Bachireddy P, Felsher DW. Cellular senescence is an important mechanism of tumor regression upon c-Myc inactivation. Proc Natl Acad Sci U S A. 2007;104:13028-33.

32. Chou T-Y, Hart GW, Dang CV. C-Myc is glycosylated at threonine 58, a known phosphorylation site and a mutational hot spot in lymphomas. J Biol Chem. 1995;270:18961-5.

33. Osaka E, Suzuki T, Osaka S, Yoshida Y, Sugita H, Asami S, et al. Survivin as a prognostic factor for osteosarcoma patients. Acta Histochem Cytochem. 2006;39:95-100.

34. Wu Y, Liang X, Liu Y, Gong W, Liu J, Wang X, et al. + Antisense oligonucleotide targeting survivin inhibits growth by inducing apoptosis in human osteosarcoma cells MG-63. Neoplasma. 2009;57:501-6.

35. Pagano M, Theodoras AM, Tam SW, Draetta GF. Cyclin D1-mediated inhibition of repair and replicative DNA synthesis in human fibroblasts. Gene Develop. 1994;8:1627-39.

36. Furlanetto RW, Harwell SE, Frick KK. Insulin-like growth factor-l induces cyclin-D1 expression in MG63 human osteosarcoma cells in vitro. Molecular Endocrinol. 1994;8:510-7.

37. Turpeenniemi-Hujanen T. Gelatinases (MMP-2 and-9) and their natural inhibitors as prognostic indicators in solid cancers. Biochimie. 2005;87:287-97.

38. Sato H, Kida Y, Mai M, Endo Y, Sasaki T, Tanaka J, et al. Expression of genes encoding type IV collagen-degrading metalloproteinases and tissue inhibitors of metalloproteinases in various human tumor cells. Oncogene. 1992;7:77-83.

39. Felx M, Guyot M, Isler M, Turcotte R, Doyon J, Khatib A, et al. Endothelin-1 (ET-1) promotes MMP-2 and MMP-9 induction involving the transcription factor NF-kappaB in human osteosarcoma. Clin Sci. 2006;1 10:645-54.

40. Haydon RC, Deyrup A, Ishikawa A, Heck R, Jiang W, Zhou L, et al. Cytoplasmic and/or nuclear accumulation of the $\beta$-catenin protein is a frequent event in human osteosarcoma. Int J Cancer. 2002;102:338-42.

41. Amit S, Hatzubai A, Birman Y, Andersen JS, Ben-Shushan E, Mann M, et al. Axin-mediated CKI phosphorylation of $\beta$-catenin at Ser 45: a molecular switch for the Wnt pathway. Gene Develop. 2002;16:1066-76.

42. Xu X, Mao W, Chen Q, Zhuang Q, Wang L, Dai J, et al. Endostar, a modified recombinant human endostatin, suppresses angiogenesis through inhibition of Wnt/B-catenin signaling pathway. Plos One. 2014;9, e107463.

\section{Submit your next manuscript to BioMed Central and take full advantage of:}

- Convenient online submission

- Thorough peer review

- No space constraints or color figure charges

- Immediate publication on acceptance

- Inclusion in PubMed, CAS, Scopus and Google Scholar

- Research which is freely available for redistribution 